\title{
Pengaruh Customer Relationship Management dan Kualitas Layanan Terhadap Kepuasan dan Loyalitas Pelanggan Media Advertising di Samarinda
}

\author{
(Effect of CRM and Service Quality on Customer Satisfaction and \\ Customer Loyality of Advertising Media in Samarinda)
}

\author{
Ade Saputri, Syarifah Hudayah, Zainal Abidin* \\ Program Magister Manajemen Fakultas Ekonomi dan Bisnis \\ Universitas Mulawarman Samarinda (75117) Indonesia \\ E-mail: zainal.abidin@feb.unmul.ac.id
}

\begin{abstract}
Abstrak
Tujuan penelitian ini adalah untuk menganalisis pengaruh customer relationship management (CRM) dan kualitas layanan (KL) terhadap kepuasan (KEP) dan loyalitas pelanggan (LP) perusahaan media advertising di Samarinda. Populasi dalam penelitian ini adalah pelanggan perusahaan media advertising di Samarinda. Dengan menggunakan teknik pengambilan sampel accidental sampling sampel dalam penelitian ini sebanyak 100 responden. Analisis dalam penelitian ini adalah analisis jalur dengan program SPSS. Hasil penelitian menunjukkan bahwa CRM berpengaruh positif dan signifikan terhadap KEP, CRM berpengaruh positif dan signifikan terhadap LP, KL berpengaruh positif dan signifikan terhadap KEP, KL berpengaruh positif dan signifikan terhadap LP media advertising di Kota Samarinda.
\end{abstract}

Kata Kunci: manajemen hubungan pelanggan, kualitas layanan, kepuasan, loyalitas.

\begin{abstract}
The purpose of this study was to analyze the effect of customer relationship management and service quality on customer satisfaction and loyalty of advertising media companies in Samarinda. The population in this study were customers of advertising media companies in Samarinda. Using accidental sampling, the sample in this study was 100 respondents. The analysis in this study is path analysis with the SPSS program. The results showed that CRM has a positive and significant effect on customer satisfaction, CRM has a positive and significant effect on customer loyalty, service quality has a positive and significant effect on customer satisfaction, service quality has a positive and significant effect on customer loyalty in advertising media in Samarinda city.
\end{abstract}

Keywords: customer relationship management, service quality, customer satisfaction, customer loyalty.

\section{Pendahuluan}

Persaingan antar media advertising di Samarinda meningkat dari tahun ke tahun. Hal tersebut dapat dibuktikan dengan semaikn banyak bermunculan perusahaan sejenis baik secara lokal serta asing. Maka dari itu, penting bagi perusahaan media advertising untuk mengembangkan strategi seperti mengelola setiap produknya secara unik dan memberikan jasa yang berkualitas sehingga dapat memberikan keunggulan dibandingkan dari pesaing atau perusahaan media advertising lainnya.

Menciptakan pelayanan yang berkualitas serta meningkatkan kualitas jasa dapat menumbuhkan kepuasan (KEP) serta loyalitas pelanggan (LP). Faktor terpenting persaingan bisnis dalam menyedia layanan kepada para pelanggan yaitu kualitas dari pelayanan, KEP serta LP (Zeithaml et al., 1996). Kualitas Layanan (KL) merupakan peran penting dalam meningkatkan KEP serta niat untuk berkunjung kembali, sehingga penting bagi perusahaan jasa untuk menyediakan layanan berkualitas bagi pelanggan, sehingga tercipta KEP dan retensi (mempertahankan) pelanggan (Lee et al., 2011).

Iriandini et al. (2015) dalam penelitiannya menyatakan bahwa mempertahankan pelanggan juga dapat dengan cara menjalin hubungan dengan pelanggan atau customer relationship management (CRM). Hubungan yang baik dengan pelanggan dinyatakan sebagai metode perusahaan untuk menciptakan hubungan yang saling menguntungkan secara jangka panjang dan berharga (Hayati et al., 2020). Selain itu hubungan pelanggan dapat membangun citra perusahaan yang positif dalam benak pelanggan, yang kemudian dapat mempengaruhi tingkat LP dari pelanggan yang puas pada kinerja perusahaan (Zhang et al., 2016).

Perusahaan media advertising di Samarinda yang bergerak pada sektor jasa ini umumnya sudah berkembang dari tahun ketahun dan mulai banyak dikenal oleh para warga sekitar (lama/baru) dan para konsumen yang tentunya sudah menjadi langganan di perusahaan-perusahaan media advertising di Samarinda. Suatu pelayanan adalah sesuatu yang tak berwujud. Dalam menghadapi persaingan, manajemen perusahaan media advertising di Samarinda perlu melakukan peningkatan pelayanan agar para pelanggan tidak akan beralih ke perusahaan sejenis lainnya, dengan kata lain pelanggan harus memiliki sifat LPyang tinggi bagi perusahaan. Pelayanan yang diberikan menjadi sebuah penilaian dari pelanggan untuk memilih bahkan loyal terhadap perusahaan tersebut. LP berperan penting bagi perkembangan perusahaan di masa mendatang, dengan demikian perusahaan perlu membina hubungan yang baik

\footnotetext{
* Corresponding author
} 
dengan pelanggan sehingga LPakan terbentuk (Griffin, 2005).

Diharapkan dengan cara tersebut pelanggan yang telah ada mampu mempengaruhi pelanggan yang lain bahwa perusahaan tersebut pelayanannya baik. Sehingga dengan informasi tersebut diharapkan pelanggannya semakin banyak serta pelanggan lama akan semakin loyal dan tidak berupaya untuk mencari informasi maupun pindah ke perusahaan jasa lainnya. Walalupun banyak pelanggan yang menggunakan jasa perusahaan media advertising sebagai media iklan tersebut, masih sedikit penelitian yang memfokuskan pada media advertising terhadap KEP dan LP. Dengan demikian penelitian ini bertujuan untuk untuk menganalisis pengaruh CRM dan KL terhadap KEP dan LP perusahaan media advertising di Samarinda.

\section{Kajian Teori dan Hipotesis}

\section{Customer Relationship Management (CRM)}

Menurut Lupiyoadi (2009:6) CRM berfokus pada proses mempertahankan pelanggan dengan membina hubungan baik perusahaan dengan pelanggannya. CRM berfokus pada pembuatan, pengelolaan, dan perluasan hubungan antara perusahaan dan pelanggannya (Bolton, 2016; Hyun \& Perdue, 2017). Maka dari itu, CRM dapat dikatakan sebagai bagian dari manajemen pemasaran di sebuah perusahaan. Chen dan Popovich (2003) menunjukkan tiga aspek utama dari CRM, yaitu teknologi, manusia dan proses. Teknologi membantu proses perusahaan dalam aktivitas mengelola hubungan dengan pelanggan, lalu manusia sebagai pelaksana dari aktivitas tersebut, sedangkan proses merupakan sistem yang digunakan manusia dalam aktivitasnya mengelola hubungan dengan pelanggan. Hubungan pelanggan diuji dengan dimensi manajemen hubungan pelanggan yang terdiri dari kompetensi, komunikasi, penanganan konflik, kepercayaan, dan kualitas hubungan (Padmavathy et al., 2012).

\section{Kualitas Layanan (KL)}

KL adalah penilaian keseluruhan pelanggan atas kinerja penyedia layanan (Lien et al., 2014) dan menjadi perhatian utama dalam literatur pemasaran jasa (Malhotra et al., 2005). Parasuraman et al. (1988) mengukur KL dengan lima dimensi, yaitu bukti fisik, keandalan, ketanggapan, jaminan, dan empati.

\section{Kepuasan Pelanggan (KEP)}

KEP didefinisikan sebagai evaluasi pelanggan setelah pembelian dimana hasil yang didapat sesuai harapan atau melebihi harapan tersebut, sedangkan ketidakpuasan muncul ketika hasil tidak sesuai dengan harapan atau dengan kata lain, perasaan pelanggan setelah membandingkan hasil yang didapat dengan harapan awal (Tjiptono, 2014). KEP juga dapat dinyatakan sebagai pilihan setelah evaluasi penilaian atas transaksi tertentu (Cronin Jr \& Taylor, 1992). KEP diukur dengan menggunakan indikator dari penelitian (Dimitriades, 2006) yaitu, KEP keseluruhan, pemenuhan ekspektasi pelanggan yang konstan, pengalaman yang menarik dan tidak mengabaikan perusahaan.

\section{Loyalitas Pelanggan (LP)}

Pearson (1996) mendefinisikan LP sebagai pola pikir pelanggan untuk mempertahankan perilaku positif terhadap perusahaan, komitmen untuk membeli kembali produk atau layanan perusahaan, dan merekomendasikan perbaikan produk dan layanan kepada orang lain. LPdapat diukur dengan indikator mulut ke mulut, pembelian kembali, identifikasi, dan rekomendasi kepada pelanggan lain (Cronin et al., 2000; Cronin Jr \& Taylor, 1992).

\section{Hubungan CRM dan KEP}

Tujuan utama pemasaran dapat dicapai dengan terciptanya KEP. KEP perlu dibentuk secara total, hal ini dikarenakan KEP secara kecil atau sebagian tidak akan cukup untuk membuat pelanggan berniat untuk menggunakan kembali suatu jasa. Maka dari itu pelanggan secara total mampu membuat peluang untuk dapat membeli kembali, dan memperkecil kemungkinan untuk beralih ke perusahaan sejenis lainnya (Barnes, 2001).

Hal tersebut didukung dari penelitian (Sirait, 2018) yang menunjukkan bahwa CRM dan KL mempengaruhi KEP secara positif dan signifikan. Selain itu Hassan et al. (2015) menyatakan bahwa CRM mempengaruhi KEP secara signifikan dan kedua variabel tersebut memiliki hubungan positif. Perusahaan menjadikan CRM-nya sebagai kuat dan dapat diandalkan pelanggan akan lebih puas dan mempertahankan dengan perusahaan. Berdasarkan uraian tersebut, hipotesis ditunjukkan sebagai berikut:

\section{H1: $C R M$ mempengaruhi KEP secara positif dan signifikan.}

\section{Hubungan $C R M$ dan LP}

Abdurrahman (2015:9) menyatakan bahwa CRM bukan hanya melayani, akan tetapi perusahaan dapat mengevaluasi keinginan pelanggan dengan menjalin hubungan dengan mereka sehingga perusahaan dapat mengetahui dan dapat memberikan pelayanan sesuai dengan keinginan pelanggan. Dengan demikian pelanggan akan menjadi loyal.

Berdasarkan penelitian dari (Amoako et al., 2012) yang menunjukkan bahwa CRM mempengaruhi LP secara positif dan signifikan. Hal tersebut juga didukung dengan berbagai penelitian terdahulu oleh (Alipour \& Mohammadi, 2011) yang mendapatkan hasil bahwa CRM mempengaruhi LP secara positif dan signifikan. Dengan demikian hipotesis selanjutnya adalah sebagai berikut:

H2: $C R M$ mempengaruhi LP secara positif dan signifikan.

\section{Hubungan KL dan KEP}

KEP dijelaskan sebagai harapan pelanggan yang terpenuhi atas kinerja suatu merek (Tse et al., 1988), dimana hal tersebut merupakan konstruksi yang terkait erat dengan KL (Mägi \& Julander, 1996). Hal tersebut didukung dengan hasil penelitian sebelumnya (Setiawan, 2014) yang meneliti pengaruh KL terhadap KEP, dimana menunjukkan temuan bahwa KL Kampoeng Kidz memiliki pengaruh terhadap KEP secara signifikan. Maka dari itu, meningkatkan faktor-faktor yang mempengaruhi KL merupakan langkah penting bagi Kampoeng Kidz untuk membentuk KEP dalam menghadapi persaingan bisnis wisata edukasi yang semakin tinggi. Leninkumar (2016) juga menyatakan dalam penelitiannya bahwa hubungan jalur yang dihipotesiskan antara variabel KL terhadap KEP adalah positif tetapi tidak signifikan secara statistik. Penelitian saat ini bertepatan dengan temuan penelitian sebelumnya dalam memeriksa hubungan antara dimensi KL dan kepu pelanggan dalam konteks yang berbeda. Dengan demikian hipotesis selanjutnya adalah sebagai berikut: 
H3: KL mempengaruhi KEP secara positif dan signifikan.

\section{Hubungan KL dan LP}

Dalam pelaksanaannya KL dapat mempengaruhi LP terhadap perusahaan yang telah dipercayanya. KL menjadi prediktor utama yang dapat mempengaruhi LP dikarenakan pelanggan yang mendapatkan pelayanan yang berkualitas akan memiliki LPyang tinggi. Hal tersebut dapat diberikan alasan jika pelanggan telah cocok dengan pelayanan yang diberikan, maka pelanggan akan terus menggunakan pelayanan pada suatu perusahaan. Alasan lainnya juga dikarenakan butuh beberapa proses bagi pelanggan dalam menentukan perusahaan yang akan dikunjungi, sehingga ketika mendapatkan perusahaan yang sesuai dengan harapan maka pelanggan akan bertahan pada perusahaan tersebut. Selain itu, jika pelayanan yang diberika buruk atau KL rendah dari yang diharapkan pelanggan, maka pelanggan akan beralih ke perusahaan sejenis lainnya.

Penelitian terdahulu yang diteliti oleh Kalalo (2013) menyatakan bahwa KL mempengaruhi LP secara signifikan. Hal tersebut juga didukung dengan berbagai penelitian terdahulu oleh (Nyadzayo \& Khajehzadeh, 2016) yang juga menunjukkan hasil bahwa meskipun LP dipengaruhi oleh KL, KEP dan nilai pelanggan, hubungan ini semakin diperkuat ketika pelanggan merasakan kualitas CRM yang lebih tinggi. Dengan demikian hipotesis selanjutnya adalah sebagai berikut:

H4: KL mempengaruhi LP secara positif dan signifikan.

\section{Metode}

\section{Populasi dan Sampel}

Pelanggan perusahaan media advertising di Samarinda menjadi populasi penelitian. Metode pengambilan sampel dilakukan dengan cara Accidental Sampling yang didefinisikan sebagai bentuk pengambilan sampel berdasarkan kebetulan atau accidental, dimana peneliti bertemu dengan siapa saja secara kebetulan dan dianggap cocok untuk menjadi responden penelitian (Sugiyono, 2014). Selain itu Accidental Sampling digunakan karena besarnya jumlah populasi yaitu pelanggan media advertising di samarinda, maka Accidental Sampling dikatan cocok digunakan dengan menggunakan rumus slovin. Perusahaan media advertising di Samarinda memiliki rata-rata pelanggan per hari berkisar 10 sampai 40 pelanggan. Peneliti mengambil batasan teratas yaitu 40 pelanggan sebagai populasi, maka seluruh perusahaan advertising di Samarinda yang berjumlah 29 perusahaan memiliki sebanyak 1.160 pelanggan. Hasil perhitungan menggunakan rumus Slovin dapat ditunjukkan sebagai berikut:

$$
n=\frac{1.160}{1+\left(1.160 \mathrm{x}(0,1)^{2}\right)}=92,03
$$

Oleh karena itu, dari dua pendekatan yaitu Slovin dan Hair, peneliti memutuskan untuk mengambil sampel sebanyak 100 responden. Pertimbangan peneliti dalam memilih sampel dengan jumlah sebanyak 100 responden ialah didukung oleh saran (Hair et al, 2014:10) yang menyatakan bahwa jumlah sampel 100 telah memenuhi syarat sebagai sampel.

\section{Analisis Data}

Analisis jalur atau path analysis digunakan dalam penelitian ini, dimana bertujuan untuk menganalisis pola hubungan antar variabel. Selain itu, analisis jalur digunakan untuk mengidentifikasi pengaruh langsung maupun tidak langsung dari variabel yang telah diajukan. Pengaruh dalam analisis ini ditunjukkan dari nilai koefisien pada setiap diagram jalur dari hubungan variabel independen dan dependen.

\section{Uji F (simultan) dan Uji t (parsial)}

Uji F dinyatakan sebagai uji secara simultan atau serempak yang dilakukan untuk mengidentifikasi apakah variabel independen secara bersama-sama mempengaruhi variabel dependen secara signifikna serta dapat membuktikan hipotesis yang telah diajukan dalam suatu penelitian.

Sedangkan Uji $t$ digunakan dalam mengidentifikasi kemaknaan hubungan variabel independen terhadap variabel dependen dan sekaligus untuk membuktikan hipotesis yang diajukan. Pengujian ini dilakukan dengan membandingkan $t_{\text {hitung }}$ dan $t_{\text {tabel }}$ pada derajat signifikan $5 \%(\alpha=0,05)$. Jika nilai $t_{\text {hitung }} \geq \mathrm{t}_{\text {tabel }}$, maka $\mathrm{H}_{0}$ ditolak dan $\mathrm{H}_{1}$ diterima yang mengindikasikan jika hipotesis yang diajukan dalam penelitian ini dapat diterima atau disetujui.

\section{Uji Koefisien Determinasi $\left(\mathbf{R}^{2}\right)$}

Koefisien determinasi $\left(\mathrm{R}^{2}\right)$ digunakan untuk mengukur bagaimana suatu model dalam menjelaskan variasi dari variabel dependen. Sedangkan nilai koefisien determinasi memiliki nilai antara nol dan satu. $\mathrm{R}^{2}$ yang memiliki nilai rendah mengindikasikan kemampuan dari beberapa variabel independen dalam menerangkan variasi variabel dependen. Nilai yang mendekati satu mengindikasikan variabel independen memberikan hampir keseluruhan informasi yang dibutuhkan dalam meramal variasi variabel dependen. (Ghozali, 2011).

\section{Hasil dan Pembahasan}

Hasil analisis jalur dan pengujian hipotesis dijelaskan pada tabel sebagai berikut:

Tabel 1. Nilai Koefisien Jalur dan Pengujian Hipotesis

\begin{tabular}{ccccc}
\hline Variable & $\begin{array}{c}\text { Standardized } \\
\text { Coefficient }(\beta)\end{array}$ & t-Statistic & Sig \\
\hline CRM & KEP & 0,177 & 2,468 & 0,015 \\
KL & KEP & 0,667 & 9,327 & 0,000 \\
CRM & LP & 0,226 & 2,521 & 0,013 \\
KL & LP & 0,411 & 4,588 & 0,000
\end{tabular}

Sumber: Pengolahan data SPSS ver. 23.0, 2020.

Standardized Coefficient Beta pada pengujian hipotesis pertama memiliki nilai 0,177 yang dinyatakan sebagai nilai path atau jalur. Sedangkan t-hitung pada variabel CRM terhadap KEP memiliki nilai 2,468 dengan nilai signifikasi 0,015 Nilai signifikasi mengacu pada nilai $\alpha$ sebesar 0,05 , sehingga hasil analisis menyatakan jika CRM mempengaruhi KEP secara positif dan signifikan. Berdasarkan hal tersebut hasil analisis mendukung hipotesis pertama.

Standardized Coefficient Beta pada pengujian hipotesis kedua memiliki nilai 0,226 yang dinyatakan sebagai nilai path atau jalur. Sedangkan t-hitung pada variabel CRM terhadap LP memiliki nilai 2,521 dengan nilai signifikasi 0,013 Nilai signifikasi mengacu pada nilai $\alpha$ sebesar 0,05 , sehingga hasil 
analisis menyatakan jika $C R M$ mempengaruhi LP secara positif dan signifikan. Berdasarkan hal tersebut hasil analisis mendukung hipotesis kedua.

Pada pengujian hipotesis selanjutnya, Standardized Coefficient Beta memiliki nilai 0,667 yang dinyatakan sebagai nilai path atau jalur. Sedangkan t-hitung pada variabel KL terhadap KEP memiliki nilai 9,327 dengan nilai signifikasi 0,000 Nilai signifikasi mengacu pada nilai $\alpha$ sebesar 0,05, sehingga hasil analisis menyatakan jika KL mempengaruhi KEP secara positif dan signifikan. Berdasarkan hal tersebut hasil analisis mendukung hipotesis ketiga.

Sedangkan untuk pengujian hipotesis keempat, Standardized Coefficient Beta memiliki nilai 0,411 yang dinyatakan sebagai nilai path atau jalur. Sedangkan t-hitung pada variabel KL terhadap LP memiliki nilai 4,588 dengan nilai signifikasi 0,015 Nilai signifikasi mengacu pada nilai $\alpha$ sebesar 0,05, sehingga hasil analisis menyatakan jika KL mempengaruhi LP secara positif dan signifikan. Berdasarkan hal tersebut hasil analisis mendukung hipotesis keempat.

Sesuai dengan model penelitian, dihasilkan fungsi model substruktur 1 dan fungsi model sub-struktur 2. Kedua fungsi yang dihasilkan tersebut secara simultan tergabung menjadi model jalur. Pengaruh antara eksogen dan endogen dijelaskan sebagai berikut:

Pada fungsi-1 (sub-struktur 1 ) variabel eksogen $=\mathrm{CRM}, \mathrm{KL}$ dan variabel endogen $=\mathrm{KEP}$

Pengaruh langsung terhitung seperti pada standardize regression weight (koefisien). Pada fungsi-1, CRM dan KL tidak mempunyai pengaruh tidak langsung pada KEP. Total pengaruh masing-masing variabel eksogen terhadap KEP sama dengan pengaruh langsungnya. Penulisan fungsi atau model-1 dalam bentuk terstandar adalah:

$$
\mathrm{KEP}=0,177 \mathrm{CRM}+0,667 \mathrm{KL}
$$

Berdasarkan model path yang telah ditunjukkan, selanjutnya dapat diinterprestasikan sebagai berikut, Koefisien CRM sebesar 0,177 artinya jika variabel bebas lainnya memiliki nilai tetap dan CRM naik satu angka, maka KEP akan meningkat sebesar 0,177 . Koefisien bernilai positif artinya terdapat hubungan yang positif antara $C R M$ dengan KEP, dimana semakin tinggi $C R M$ maka akan semakin tinggi pula KEP.

Sedangkan pada koefisien KL sebesar 0,667 artinya jika variabel bebas lainnya memiliki nilai tetap dan KL meningkat satu angka, maka KEP akan mengalami kenaikan sebesar 0,667 . Koefisien bernilai positif artinya terjadi hubungan positif antara KL terhadap KEP, dimana semakin tinggi KL maka akan semakin tinggi pula KEP.

Pada fungsi-2 (sub-struktur 2) variabel eksogen = CRM, KL dan variabel endogen $=\mathrm{LP}$

Pengaruh langsung terhitung seperti pada standardize regression weight (koefisien). Pada fungsi-2, CRM dan KL tidak mempunyai pengaruh tidak langsung pada LP. Total pengaruh masing-masing variabel eksogen terhadap LP sama dengan pengaruh langsungnya. Penulisan fungsi atau model-2 dalam bentuk terstandar adalah:

$$
\mathrm{LP}=0,226 \mathrm{CRM}+0,411 \mathrm{KL}
$$

Berdasarkan model path yang telah ditunjukkan, dimana dapat diinterpretasikan bahwa koefisien CRM sebesar 0,226 yang mengindikasikan jika variabel bebas lainnya memiliki nilai tetap dan persepsi CRM meningkat satu angka, maka LP akan meningkat sebesar 0,226. Koefisien bernilai positif mengindikasikan adanya hubungan positif antara $C R M$ terhadap LP.

Sedangkan koefisien persepsi KL memiliki nilai sebesar 0,411 artinya jika variabel bebas lainnya memiliki nilai tetap dan KL meningkat satu angka, maka LP akan meningkat sebesar 0,411. Koefisien bernilai positif mengindikasikan adanya hubungan positif antara KL terhadap LP.

Dengan demikian dapat disimpulkan bahwa pengaruh langsung CRM dan KL terhadap KEP pada sub-struktur 1 dan pengaruh langsung CRM dan KL terhadap LP pada substruktur 2 yang telah dijelaskan di atas memiliki nilai koefisien jalur yang hasilnya sama-sama besar.

\section{Uji F (Simultan)}

Uji F dianalisis menggunakan analisis regresi dengan bantuan aplikasi SPSS 23.0. Hasil pengujian ditunjukkan pada Tabel 2.

Tabel 2. Hasil Analisis Uji ANOVA Terhadap KEP

\begin{tabular}{cc}
\hline $\mathrm{F}$ & Sig. \\
\hline 54.950 & $0.000^{\mathrm{b}}$ \\
\hline
\end{tabular}

Sumber: Pengolahan data SPSS ver. 23.0, 2020.

Berdasarkan tabel di atas dapat diketahui bahwa $\mathrm{F}_{\text {hitung }}=$ 54,950, sedangkan $F_{\text {tabel }}=3,09$ diperoleh dari perhitungan df1 $=$ jumlah variabel $-1 \quad(3-1=2)$, dan $\mathrm{df} 2=(\mathrm{n}-\mathrm{k}-1)$ jumlah sampel - jumlah variabel - 1 variabel 100-3-1=96 tabel distribusi $\mathrm{F}$ dengan taraf signifikan 0,05. Dari perhitungan tersebut dapat dilihat bahwa $\mathrm{F}_{\text {hitung }}>\mathrm{F}_{\text {tabel. }}$.

Maka dapat disimpulkan, karena $\mathrm{F}_{\text {hitung }}>\mathrm{F}_{\text {tabel }} \quad(54,950>$ 3,09) maka Ho ditolak dan Ha diterima artinya antara variabel independen CRM dan KL secara simultan mempunyai pengaruh terhadap variabel dependen KEP.

Tabel 3. Hasil Analisis Uji ANOVA Terhadap LP

\begin{tabular}{cc}
\hline $\mathrm{F}$ & Sig. \\
\hline 17.365 & $0.000^{\mathrm{b}}$ \\
\hline
\end{tabular}

Sumber: Pengolahan data SPSS ver. 23.0, 2020.

Berdasarkan tabel di atas dapat diketahui bahwa $\mathrm{F}_{\text {hitung }}=$ 17,365 , sedangkan $F_{\text {tabel }}=3,09$ diperoleh dari perhitungan df1 $=$ jumlah variabel $-1 \quad(3-1=2)$, dan df2 $=(n-k-1)$ jumlah sampel - jumlah variabel - 1 variabel 100-3-1=96 tabel distribusi $\mathrm{F}$ dengan taraf signifikan 0,05. Dari perhitungan tersebut dapat dilihat bahwa $\mathrm{F}_{\text {hitung }}>\mathrm{F}_{\text {tabel }}$.

Maka dapat disimpulkan, karena $\mathrm{F}_{\text {hitung }}>\mathrm{F}$ tabel $(17,365>$ 3,09) maka Ho ditolak dan Ha diterima artinya antara variabel independen $C R M$ dan $\mathrm{KL}$ secara simultan mempunyai pengaruh terhadap variabel dependen LP.

\section{Uji t (parsial)}

Uji $\mathrm{t}$ dianalisis menggunakan program perhitungan IBM SPSS 23.0, dengan taraf signifikasi $5 \%$ yaitu 0,05 . Syarat diterimanya hipotesis adalah nilai $\mathrm{t}_{\text {hitung }}$ harus diatas $\mathrm{t}_{\text {tabel. }}$. 
Tabel 4. Hasil Analisis Uji t Terhadap KEP

\begin{tabular}{cccc}
\hline $\begin{array}{c}\text { Unstandardized } \\
\text { Coefficients }\end{array}$ & $\begin{array}{c}\text { Standardized } \\
\text { Coefficients }\end{array}$ & \multirow{2}{*}{$\mathrm{t}$} & Sig. \\
\cline { 1 - 3 } $\mathrm{B}$ & Beta & & \\
\hline 0,141 & 0,177 & 2,468 & 0,015 \\
0,709 & 0,667 & 9,327 & 0,000 \\
\hline
\end{tabular}

Sumber: Pengolahan data SPSS ver. 23.0, 2020.

Berdasarkan tabel diatas menjelaskan bahwa pada level of significant $5 \%$ atau 0,05 , diperoleh $\mathrm{t}_{\text {hitung }}$ untuk variabel $C R M$ sebesar 2,468 dengan nilai signifikan t sebesar $0,015<0,05$ dan KL sebesar 9,327 dengan nilai signifikan t sebesar 0,000 $<0,05$. Dengan demikian variabel $C R M$ dan KL terbukti secara statistik berpengaruh positif dan signifikan terhadap variabel KEP.

Tabel 5. Hasil Analisis Uji t Terhadap LP

\begin{tabular}{cccc}
\hline $\begin{array}{c}\text { Unstandardized } \\
\text { Coefficients }\end{array}$ & $\begin{array}{c}\text { Standardized } \\
\text { Coefficients }\end{array}$ & \multirow{2}{*}{$\mathrm{t}$} & Sig. \\
\cline { 1 - 3 } $\mathrm{B}$ & Beta & & \\
\hline 0,900 & & 2,127 & 0,036 \\
0,191 & 0,226 & 2,521 & 0,013 \\
0,463 & 0,411 & 4,588 & 0,000 \\
\hline
\end{tabular}

Sumber: Pengolahan data SPSS ver. 23.0, 2020.

Berdasarkan tabel diatas menjelaskan bahwa pada level of significant $5 \%$ atau 0,05 , diperoleh $\mathrm{t}_{\text {hitung }}$ untuk variabel $C R M$ sebesar 2,127 dengan nilai signifikan t sebesar $0,013<0,05$ dan KL sebesar 4,588 dengan nilai signifikan t sebesar 0,000 $<0,05$. Dengan demikian variabel $C R M$ dan KL terbukti secara statistik berpengaruh positif dan signifikan terhadap variabel LP.

\section{Uji Koefisien Determinasi $\left(\mathbf{R}^{\mathbf{2}}\right)$}

Tabel 6. Koefisien Determinasi Terhadap KEP

\begin{tabular}{cc}
\hline $\mathrm{R}$ & R Square \\
\hline $0,729^{\mathrm{a}}$ & 0,531 \\
\hline
\end{tabular}

Sumber: Pengolahan data SPSS ver. 23.0, 2020.

Dari tabel diatas hasil koefesien determinasi 0,531 atau $53,1 \%$. Ini berarti bahwa variabel independen (CRM dan $\mathrm{KL})$ memiliki pengaruh sebesar $53,1 \%$ terhadap variabel dependen (KEP), sedangkan 46,9\% (100\%-53,1\%) dijelaskan oleh faktor lain yang berada diluar model penelitian ini.

Dari tabel diatas hasil koefesien determinasi 0,264 atau $26,4 \%$. Ini berarti bahwa variabel independen (CRM dan $\mathrm{KL})$ memiliki pengaruh sebesar $26,4 \%$ terhadap variabel dependen (KEP), sedangkan 73,6\% (100\%-26,4\%) dijelaskan oleh faktor lain yang berada diluar model penelitian ini.

\section{Pembahasan}

Temuan dari penelitian ini berdasarkan hasil analisis menunjukkan bahwa CRM memiliki pengaruh positif dan signifikan terhadap KEP dan LP media advertising di Kota Samarinda. Hasil ini mengindikasikan bahwa hubungan yang baik dengan pelanggan akan meningkatkan KEP dan LP. Hasil penelitian variabel hubungan pelanggan ini mendukung penelitian dari Sirait (2018) dan Hassan et al. (2015) yang menemukan jika CRM mempengaruhi KEP media advertising di Kota Samarinda. Selain itu, hasil penelitian Amoako et al. (2012) menunjukkan jika CRM berpengaruh signifikan terhadap LP. Perusahaan media advertising di Kota Samarinda dapat meningkatkan KEP dan LP dengan memperhatikan peningkatan kompetensi, komunikasi, penanganan konflik, kepercayaan, dan kualitas hubungan. Maka dari itu perusahaan Media advertising di Kota Samarinda dapat mengembangkan strategi CRM untuk meningkatkan profitabilitas perusahaan melalui KEP dan LP. Sehingga, untuk mengembangkan dan menerapkan CRM perusahaan memerlukan proses dalam meneliti karakteristik pelanggan, sehingga perusahaan mengetahui dan mengevaluasi apa yang sebenarnya diharapkan oleh pelanggan.

Hasil temuan penelitian juga menemukan adanya pengaruh positif dan signifikan pada KL terhadap KEP dan LP media advertising di Kota Samarinda. Hasil temuan ini juga mendukung penelitian yang dilakukan oleh Setiawan (2014) dan (Leninkumar, 2016), yang mendapatkan hasil jika KL memiliki pengaruh positif serta signifikan terhadap KEP media advertising di Kota Samarinda. Penelitian dari Kalalo (2013) dan Nyadzayo \& Khajehzadeh (2016) menemukan jika KL memiliki pengaruh signifikan terhadap LP media advertising di Kota Samarinda. Selain itu, sebuah studi yang dilakukan oleh Mägi \& Julander (1996) di antara bagian toko grosir di Swedia menunjukkan hubungan positif antara KL yang dirasakan, KEP dan LP. Mereka menunjukkan bahwa KEP dihasilkan dari KL yang dipersepsikan tinggi dan ini membuat pelanggan setia. Dengan demikian, perusahaan media advertising di Kota Samarinda hendaknya harus terus berupaya untuk mempertahankan pelayanan yang telah menjadi standar karena indikator ini merupakan salah satu faktor utama dalam memberikan KEP terhadap pelanggan. Selanjutnya, perusahaan media advertising di Kota Samarinda perlu meningkatkan fasilitas yang ada berupa ruang tunggu, fasilitas parkir dan layanan pada pengantaran produk yang telah dipesan oleh pelanggan. Dikarenakan perusahaan terkadang tidak menyediakan layanan antar barang yang telah dipesan oleh pelanggan apabila pelanggan menginginkan sistem pengantaran produk tersebut. Hal tersebut penting bagi perusahaan media advertising di Kota Samarinda untuk meningkatkan layanan agar para pelanggan akan merasa puas atas pelayanannya. Pelanggan perusahaan media advertising di Kota Samarinda yang merasa puas terhadap KL yang diberikan akan mengarah pada sifat loyalitas.

\section{Simpulan}

Penelitian ini bertujuan untuk menganalisis pengaruh CRM dan KL terhadap KEP dan LP perusahaan media advertising di Samarinda positif dan signifikan. Hasil penelitian pada hipotesis pertama menyatakan bahwa CRM mempengaruhi KEP secara positif dan signifikan, CRM mempengaruhi LP secara positif dan signifikan, KL mempengaruhi KEP secara positif dan signifikan, KL mempengaruhi LP media advertising di Kota Samarinda secara positif dan signifikan. Berdasarkan hasil temuan dapat dikatakan jika variabel CRM dan KL berperan penting dalam menentukan KEP serta LP perusahaan media advertising di Samarinda. Dengan demikian, penelitian ini berkontribusi pada literatur retensi 
atau mempertahankan pelanggan dengan menawarkan CRM dan KL sebagai faktor penting dari KEP dan LP. Selain itu, penelitian ini berkontribusi untuk perusahaan advertising di Samarinda untuk dapat mengembangkan strategi bisnis mereka dengan para pesaing lokal maupun asing menggunakan CRM dan KL.

\section{Saran}

Penelitian selanjutnya dapat menggunakan sampel yang lebih besar. Hal tersebut bertujuan untuk memberikan gambaran lebih spesifik mengenai CRM, KL, KEP dan LP. Selain itu penelitian selanjutnya dapat menggunakan objek penelitian baik produk maupun jasa dengan menggunakan item pengukuran dari variabel $C R M, \mathrm{KL}, \mathrm{KEP}$ dan LP. Hal tersebut dikarenakan karakteristik produ dan jasa beragam sehingga dapat memberikan hasil yang lebih luas.

\section{Ucapan Terima Kasih}

Tim penulis ingin mengucapkan terima kasih kepada Perusahaan media advertising di Kota Samarinda yang telah memberikan keesempatan dan peluang untuk melakukan penelitian di Perusahaan media advertising di Kota Samarinda. Kepada teman-teman satu angkatan yang telah memberikan masukan dan saran demi kesempurnaan penelitian ini, dan seluruh pihak yang telah membantu terwujudnya penelitian ini, semoga penelitian ini dapat bermanfaat bagi ilmu pengetahuan.

\section{Referensi}

Abdurrahman, N. H. (2015). Manajemen Strategi Pemasaran. CV Pustaka Setia.

Alipour, M., \& Mohammadi, M. H. (2011). The Effect Of Customer Relationship Management (CRM) On Achieving Competitive Advantage Of Manufacturing Tractor. Global Journal of Management and Business Research, 11(5), 27-36.

Amoako, G. K., Arthur, E., Bandoh, C., \& Katah, R. K. (2012). The impact of effective customer relationship management (CRM) on repurchase: A case study of (GOLDEN TULIP) hotel (ACCRA-GHANA) African Journal of Marketing Management, 4(1), 17-29. https://doi.org/10.5897/AJMM11.104

Barnes, J. G. (2001). Secret of Customer Relationship Management (II) Andi.

Cronin, J. J., Brady, M. K., \& Hult, G. T. M. (2000). Assessing the Effects of Quality, Value, and Customer Satisfaction on Consumer Behavioral Intentions in Service Environments. Journal of Retailing, 76(2), 193218. https://doi.org/10.1016/S0022-4359(00)00028-2

Cronin Jr, J. J., \& Taylor, S. A. (1992). Measuring Service Quality: A Reexamination and Extension. The Journal of Marketing, 55-68.

Dimitriades, Z. S. (2006). Customer satisfaction, loyalty and commitment in service organizations. Management Research News, 29(12), 782-800. https://doi.org/10.1108/01409170610717817

Griffin, J. (2005). Customer Loyalty. Erlangga.

Hair, J. F., Black, W. C., Babin, B. J., \& Anderson, R. E. (2014) Multivariate Data Analysis (MVDA). In Pharmaceutical Quality by Design: A Practical Approach (Seventh Ed). Pearson Education Limited. https://doi.org/10.1002/9781118895238.ch8

Hassan, R. S., Nawaz, A., Lashari, M. N., \& Zafar, F. (2015). Effect of Customer Relationship Management on Customer Satisfaction. Procedia Economics and Finance, 23, 563-567. https://doi.org/10.1016/S2212-5671(15)00513-4
Hayati, S., Suroso, A., Suliyanto, S., \& Kaukab, M. E. (2020). Customer satisfaction as a mediation between micro banking image, customer relationship and customer loyalty. Management Science Letters, 10, 2561-2570. https://doi.org/10.5267/j.msl.2020.3.039

Iriandini, A., Yulianto, E., \& Mawardi, M. K. (2015). Pengaruh Customer Relationship Management (CRM) Terhadap Kepuasan Pelanggan Dan Loyalitas Pelanggan (survey pada pelanggan PT. Gemilang libra logistics, kota surabaya). Jurnal Administrasi Bisnis S1 Universitas Brawijaya, 23(2), 85998.

Kalalo, R. E. (2013). Customer Relationship Management Dan Kualitas Pelayanan Pengaruhnya Terhadap Loyalitas Konsumen pt. Matahari dept. Store, manado. Jurnal EMBA, 1(4), 1553-1561.

Lee, Y. H., Hsieh, Y. C., \& Hsu, C. N. (2011). Adding Innovation Diffusion Theory To The Technology Acceptance Model: Supporting Employees' Intentions to Use E-Learning Systems. Journal of Educational Technology \& Society, 14(4), 124-137.

Leninkumar, V. (2016). The Effect of Service Quality on Customer Loyalty. European Journal of Business and Management, 8(33), 44-49.

Lien, C., Wu, J.-J., Chen, Y.-H., \& Wang, C.-J. (2014). Trust transfer and the effect of service quality on trust in the healthcare industry. Managing Service Quality: An International Journal, 24(4), 399-416. https://doi.org/10.1108/MSQ-11-2013-0255

Mägi, A., \& Julander, C.-R. (1996). Perceived service quality and customer satisfaction in a store performance framework. Journal of Retailing and Consumer Services, 3(1), 33-41. https://doi.org/10.1016/09696989(95)00040-2

Malhotra, N. K., Ulgado, F. M., Wu, L., Agarwal, J., \& Shainesh, G. (2005). Dimensions of Service Quality in Developed and Developing Economies: Multi-Country Cross-Cultural Comparisons. International Marketing Review, 22(3), 256-278. https://doi.org/10.1108/02651330510602204

Nyadzayo, M. W., \& Khajehzadeh, S. (2016). The antecedents of customer loyalty: A moderated mediation model of customer relationship management quality and brand image. Journal of Retailing and $\begin{array}{lll}\text { Consumer } & \text { Services, } & 30,\end{array}$ https://doi.org/10.1016/j.jretconser.2016.02.002

Padmavathy, C., Balaji, M. S., \& Sivakumar, V. J. (2012). Measuring effectiveness of customer relationship management in Indian retail banks. International Journal of Bank Marketing, 30(4), 246-266. https://doi.org/10.1108/02652321211236888

Parasuraman, A., Zeithaml, V. A., \& Berry, L. L. (1988). Servqual: A Multiple-Item Scale for Measuring Consumer Perceptions of Service Quality. Journal of Retailing, 64(1), 12-37.

Pearson, S. (1996). Building Brands Directly: Creating Business Value from Customer Relationship. McMillan Business, 116, 20.

Setiawan, A. L. (2014). Analisa Pengaruh Service Quality Dan Customer Relationship Management Terhadap Customer Loyalty Dengan Customer Satisfaction Sebagai Variabel Intervening Di Kampoeng Kidz, Batu-Jawa Timur. Jurnal Strategi Pemasaran, 1(12).

Sirait, D. P. (2018). Pengaruh Customer Relationship Management dan Kualitas Pelayanan Terhadap Kepuasan Pelanggan. Jurnal Digest Marketing, 3(1), 79-85.

Sugiyono. (2014). Metode Penelitian Kombinasi. Alfabeta.

Tjiptono, F. (2014). Pemasaran Jasa: Prinsip, Penerapan dan Penelitian. Andi Offset, Yogyakarta.

Tse, P., Scopes, R. K., Wedd, A. G., Bakshi, E., \& Murray, K. S. (1988). An iron-activated alcohol dehydrogenase: metal dissociation constants and magnetic and spectroscopic properties. Journal of the American Chemical Society, 110(4), 1295-1297. https://doi.org/10.1021/ja00212a050

Zeithaml, V. A., Berry, L. L., \& Parasuraman, A. (1996). The Behavioral Consequences of Service Quality. Journal of Marketing, 60(2), 31. https://doi.org/10.2307/1251929

Zhang, R., Li, G., Wang, Z., \& Wang, H. (2016). Relationship value based on customer equity influences on online group-buying customer loyalty. Journal of Business Research, 69(9), 3820-3826. https://doi.org/10.1016/j.jbusres.2015.12.074. 